\title{
THE UTILIZATION OF Merremia peltata FOR LIVESTOCK FEED TO CONTROL AN INVASIVE ALIEN PLANT SPECIES IN BUKIT BARISAN SELATAN NATIONAL PARK
}

\author{
R Garsetiasih*, Ragil Irianto, and Vivin S Sihombing \\ Forest Research and Development Center, Research Development and Innovation Agency, \\ Ministry of Environmental and Forestry \\ Jl. Gunung Batu No 5, Bogor 16001, West Java, Indonesia
}

Received: 14 November 2017, Revised: 2 September 2019, Accepted: 28 October 2019

\begin{abstract}
THE UTILIZATION OF Merremia peltata FOR LIVESTOCK FEED TO CONTROL AN INVASIVE ALIEN PLANT SPECIES IN BUKIT BARISAN SELATAN NATIONAL PARK. Mantangan (Merremia peltata) is a plant species which invades the habitat of herbivorous animals such as elephants and rhinos in Bukit Barisan Selatan National Park (BBSNP) Sumatera, Indonesia. One possible way to overcome the problem is by providing $M$. peltata as livestock feed. This paper observes potential use of mantangan for goat feed. The study was conducted at Tampang Tua Village, a buffer zone of BBSNP where most of communities are farmers. The study and treatment were given to 6-7 months old goat breeders with an initial weight of 7-8 kg. Additional forage feed data were collected during March to June 2014. The research was designed as Latin Square Design with four treatments and four replications. The treatments consisted of four formulations: treatment A (field grass), B (field grass $+200 \mathrm{~g}$ mantangan), C (field grass +400 $\mathrm{g}$ mantangan), and D (field grass $+600 \mathrm{~g}$ mantangan). Field grass is available continuously (ad-libitum). Result shows that the treatments significantly affect feed consumption level $(\mathrm{P}<0.05)$, but it did not have significant effect to body weight ( $>>0.05)$. In other words, mantangan is potential for animal feed. This research was conducted as an effort to manage invasive alien plant species by utilizing mantangan as feed for livestock.
\end{abstract}

Keywords: Invasive, morning glory, feed livestock, Bukit Berisan Selatan National Park

PEMANFAATAN Merremia peltata SEBAGAI PAKAN TERNAK UNTUK PENGENDALIAN SPESIES ASING INVASIF DI TAMAN NASIONAL BUKIT BARISAN SELATAN. Mantangan (Merremia peltata) adalah jenis tanaman yang menginvasi habitat satwa herbivora diantaranya gajah dan badak di Taman Nasional Bukit Barisan Selatan (TNBBS) Sumatera, Indonesia. Salah satu upaya pengendalian dilakukan dengan cara memanfaatkan mantangan sebagai pakan ternak. Tujuan penelitian ini untuke mengetahui potensi tanaman invasif mantangan dengan menggunakannya sebagai pakan kambing. Penelitian dilakukan di Desa Tampang Tua yang merupakan zona penyangga TNBBS dimana sebagian masyarakatnya peternak. Penelitian dan perlakuan diberikan pada empat ekor kambing kacang umur 6-7 bulan dengan berat awal 7-8 kg. Pengumpulan data pemanfaatan jenis tanaman invasif mantangan sebagai bijauan pakan tambahan untuk kambing dilakukan selama tiga bulan mulai bulan Maret sampai Juni 2014. Penelitian menggunakan rancangan bujur sangkar latin dengan empat perlakuan dan empat ulangan. Perlakuan yang diberikan terdiri dari empat formulasi yaitu, perlakuan A (rumput lapangan), B (rumput lapangan $+200 \mathrm{~g}$ mantangan), $C$ (rumput lapangan $+400 \mathrm{~g}$ mantangan), dan D (rumput lapangan $+600 \mathrm{~g}$ mantangan). Rumput lapangan tersedia secara terus menerus (ad-libitum). Hasil penelitian menunjukkan bahwa perlakuan berpengaruh nyata $(P<0,05)$ terbadap tingkat konsumsi pakan namun tidak berpengarub nyata $(P>0,05)$ terhadap berat badan, dengan kata lain mantangan berpotensi sebagai pakan ternak. Penelitian ini dilakukan sebagai salah satu upaya untuk mengelola tanaman invasif dengan memanfaatkan mantangan sebagai pakan untuk ternak.

Kata kunci: Invasif, mantangan, pakan ternak, TN Bukit Barisan Selatan

*Corresponding author: garsetiasih@yahoo.com 


\section{INTRODUCTION}

Bukit Barisan Selatan National Park (BBSNP) is located in the south of Sumatera Island, between Lampung and Bengkulu Provinces, Indonesia. It covers about 365,000 hectares since it was established in 1982 by the Ministry of Agriculture. BBSNP conserves habitat for wild fauna including sumatran tiger, elephant and rhino. Mantangan infestation in this area is considered as one of the causes of animal migrations to rural areas in the north, such as tiger, elephant and sumatran rhino (Irianto \& Tjitrosoedirdjo, 2010). Currently, it was reported that BBSNP had lost more than $20 \%$ of its original forest area and it has been facing serious threats of deforestation (Suyadi, 2011). This valuable remaining forest will become highly fragmented into isolated patches if current deforestation and encroachment rates continue.

The invading species has destroyed the local ecosystem and particularly farmers' plantations and grazing areas that also provided fodder for wild herbivores (deer, elephant, and rhinoceros). Such invasive action could result in a reduction in the available living and grazing space for these herbivores. Invasive alien species (IAS) is an alien species that have the ability to grow quickly on a massive scale and capable to alter the previous ecosystem (Pyŝek et al., 2015). It could surpass native species in fitness, size, and growth rate, thus reducing the living and grazing space for local herbivores (van Kleunen, Weber, \& Fischer, 2010)

At present, biodiversity in Indonesia tend to decline and unless corrective management practices are adopted, about $20-70 \%$ of the original habitat will disappear (Bappenas, 2013). This situation also resulted in the destruction of habitat due to land conversion and an excessive exploitation and the occurrence of invader species, both native (local) and exotic. One overarching character of an invasive species is that it has no enemies that are naturally capable of controlling its population (Irianto \& Tjitrosoedirdjo, 2010). Merremia peltata or locally know as mantangan is an invasive species that grown in conservation areas. Merremia peltata invaded the vegetation of Bukit Barisan Selatan National Park (BBSNP) in Lampung Province, Indonesia. In this site, the invasion has reached more than 7000 hectares (Mardiyati, 2018); this species grows very quickly in the open area and forest edges (Master et al., 2010; Yansen, 2015). The number of scientific papers about the growing threat of invasive alien species to native flora and fauna have been increasing in the last two decades (Thomaz et al., 2015).

In their new territories, alien species could expand their populations either regarding the geographical area and/or in terms of increasing frequency and density (Kolada \& Sebastian, 2016). The destruction of habitat in BBSNP caused by invader species needs to be addressed immediately by providing best practice management and controlling mantangan. As part of the efforts to control mantangan it is also important to investigate the potential of this species as animal fodder. Mantangan is similar to Ipomoea generas (socalled kangkung locally), which is utilized as green fodder. In India, areas that have been invaded by mantangan are usually used by cows for grazing, and this provides one method of control in estates areas (Paynter, Harman \& Waipara, 2006).

Controlling mantangan in BBSNP by using it as goat feedstuffs is important because this species can change the characteristic of the BBNSP's ecosystem, decrease the quality and quantity of wildlife habitat and this further will affect the pattern of wildlife behavior. Principally, this research used fresh mantangan's leave to determine effect of mantangan to body weight and level of goat's feed consumption. Research trials are needed on its use as fodder for herbivores, especially goats. The goat is one ruminant whose main food source is green field grasses (Kolada \& Sebastian, 2016). Such field grasses are usually low in protein content, which is not sufficient for either domesticated or wild ruminant. This paper explores the 
effect of mantangan to body weight and level of goat's feed consumption. This research was carried out using the domestic ruminant "bean goat" that has characteristics similar to deer both physically and biologically; Thus, if the goat is able to consume mantangan, then deer will do. The "bean goat" is an indigenous goat in Indonesia and has been widely domesticated elsewhere because it can easily adapt to new environments (Jaelani, Rostini, Zakir \& Jonathan, 2014). Mantangan is an alternative livestock feed, other than field grass, to increase the nutrition content of feed.

\section{MATERIAL AND METHOD}

\section{A. Study Site}

The study was conducted in Tampang Tua village, Kota Agung, Tanggamus District, Lampung Province, Indonesia (Figure 1). Research locations were determined by the distance between the village and Bukit Barisan Selatan National Park, and the majority of the people's livelihoods as a farmer.

\section{B. Materials}

The materials used in this research are field grass (such as buffalo grass (Paspalum conjugatum) and torpedo grass (Panicum repens)), libitum, mantangan's twig and leave, and goats. Four female bean goats aged six to seven months having a previous weight range estimated from 7 to $9 \mathrm{~kg}$ and have never been reproduced (Ismoyo \& Widiyaningrum, 2008). They were housed in four separate cage enclosure panels $(1.5 \mathrm{~m} \mathrm{x} 1 \mathrm{~m})$ with the walls and floor made from bamboo materials. Goats were fed with field grasses as their main green fodder with M. peltata (mantangan) as an added green supplement. Salt and fresh water were also made available to each goat. Other equipment consisted of an individual goat cage with a length of $110 \mathrm{~cm}$, width $50 \mathrm{~cm}$, height $80 \mathrm{~cm}$, camera, digital scale with a weighing capacity of $2 \mathrm{~kg}$, ordinary hanging scale with $50 \mathrm{~kg}$ capacity, and measurements recording on log book, and writing implements to record measurements.

\section{Research Design}

The experiment was conducted using latin square design with four replications and four treatments (Mattjik et al., 2002). The four treatments were: A: control (field grass ad libitum); B: field grass ad libitum $+200 \mathrm{~g}$ mantangan; C: field grass ad libitum $+400 \mathrm{~g}$ mantangan; and D: field grass ad libitum +600 g mantangan.
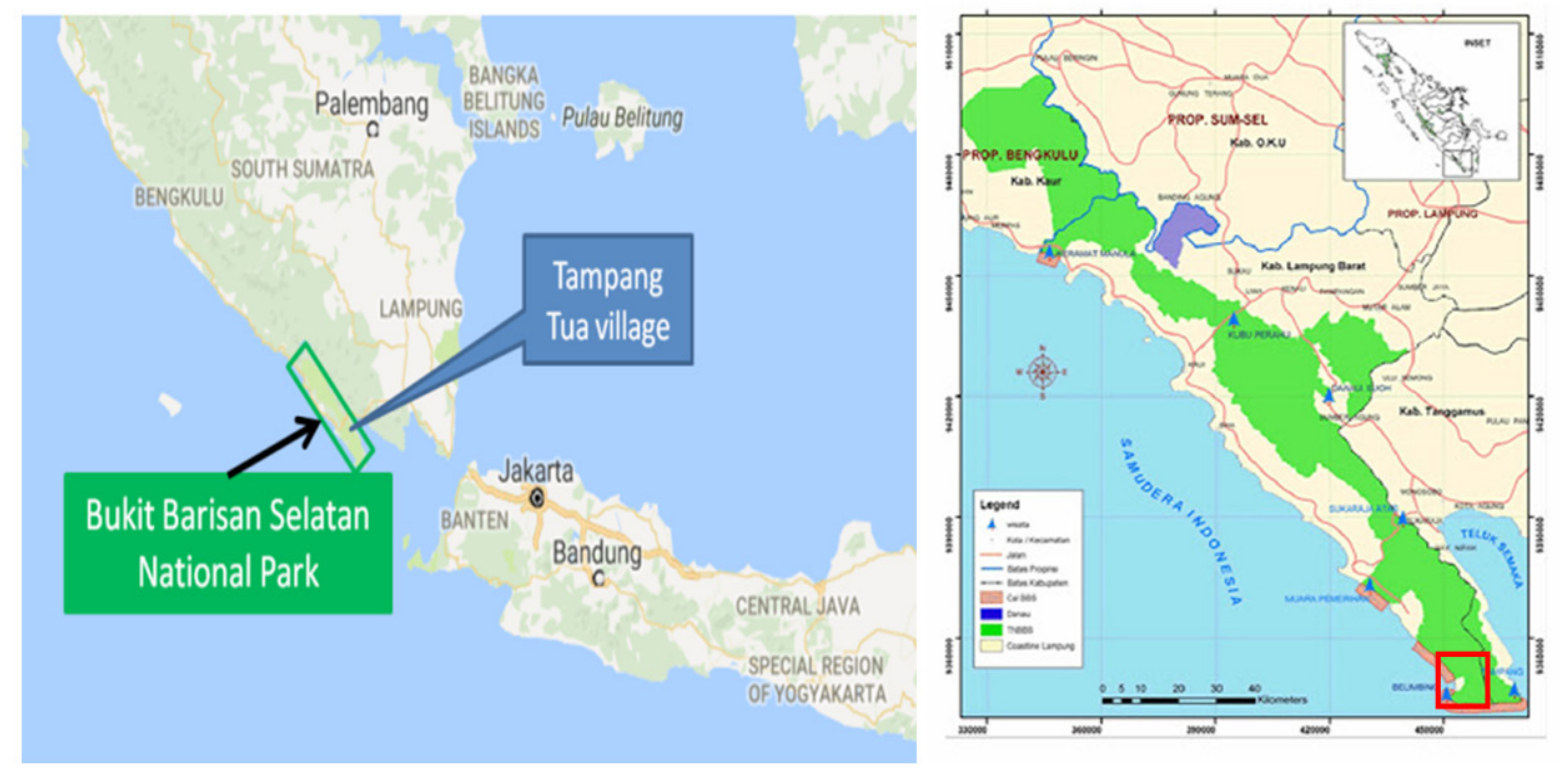

Figure 1. Research location at Tampang Tua village, Southern Sumatera, Indonesia 
The green foliar mantangan was fed at 7:00 am at the level according to each treatment. After the mantangan had been eaten by each goat, at 9:00 am field grass was made available. For each feeding of grass, the amount remaining was weighed and recorded and the new amount offered was weighed and recorded. All goats were initially weigthed prior to the experiment.

\section{Data Analysis}

The parameters measured were: (i) the consumption of fodder provided by subtracting the amount refused from the original amount offered at each feeding time plus any foliar mantangan according to the treatment used; and (ii) the body weight increment every 12 days were determined by weighing each animal using the $50 \mathrm{~kg}$ scales and substracting the previous weight. Data were analyzed quantitatively using the Minitab version 17 software package.

The mathematical model used was:

Yijk $=\mu+\alpha i+y k+\sum i j k$

where:

Yijk = value of measurements of treatment $\mathrm{k}$ at row $\mathrm{i}$ and column $\mathrm{j}$

$\mu \quad=$ mean value

$\alpha \mathrm{i} \quad=$ effect of goat $\mathrm{i} ; \mathrm{I}-\mathrm{Y}$

$\beta j \quad=$ effect of period $j ; \mathrm{I}-\mathrm{Y}$

$\mathrm{y} \cdot \mathrm{k}=$ effect of treatment $\mathrm{k} ; \mathrm{I}-\mathrm{Y}$

$\sum$ eijk $=$ base error

Treatments were tested for significance using convergence analysis (Tukey's method) according to Sall et al. (2005). The nutrient contents of the added green fodder (mantangan) were determined using proximate analysis or Weende analysis (Alikodra, 2010).

\section{RESULT AND DISCUSSION}

\section{A. Average Food Consumption}

The average consumption of each goat for each treatment is based on the total measurements for each 12 day period as shown in Figure 2. Figure 2 shows that the daily green fodder consumption trend was highest only with the field grass control treatment followed by treatment $\mathrm{D}$ (field grass $+600 \mathrm{~g}$ mantangan). In $\mathrm{D}$ treatment, the amount of field grass consumed was smaller than in any other treatment suggesting that $600 \mathrm{~g}$ mantangan was sufficient to compensate for any desire to eat more grass (available ad libitum) The green fodder requirement of herbivores is commonly $10 \%$ of the body weight (Tillman, Day, Soedomo, Suharto, \& Soekanto, 1984). While the average daily consumption for the goat in this research was more than $10 \%$ of the body weight.

The statistical testing showed that there was a significant difference in body weight among treatments at a confidence level of $\mathrm{P}<0.05$ (Table 3). The highest food consumption was achieved in treatment A (grass without mantangan), possibly because the main fodder of domestic goats is grass usually given daily so that the goats were fed according to custom

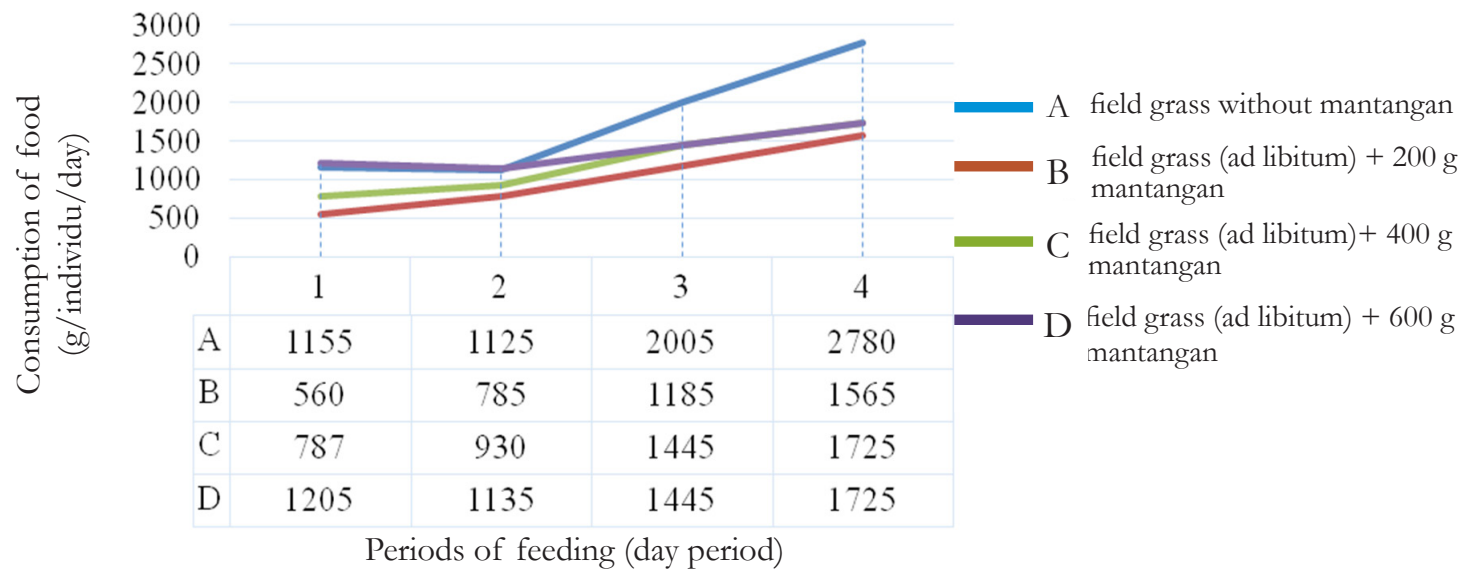

Figure 2. Trend level of food consumption 
Table 1. Average consumption of food per individual goats in each period of treatments (g/goat/day)



Remarks: A: field grass without mantangan, B: field grass (ad libitum) $+200 \mathrm{~g}$ mantangan, C: field grass (ad libitum) + $400 \mathrm{~g}$ mantangan, D: field grass (ad libitum) + $600 \mathrm{~g}$ mantangan

Table 2. ANOVA food consumption

\begin{tabular}{crrrrrr}
\hline SC & DF & \multirow{2}{*}{ SS } & MS & F-value & \multicolumn{2}{c}{ P-value } \\
\cline { 6 - 7 } & & & & & & \\
Periods & 3 & 3156472 & 1052157 & 31.04 & 0.000 & $\alpha=0.05$ \\
Goats & 3 & 144419 & 48140 & 1.42 & 0.326 & $0.326^{\text {tn }}$ \\
Treatments & 3 & 1252652 & 417551 & 12.32 & 0.006 & $0.006^{\mathrm{n}}$ \\
Error & 6 & 203373 & 33896 & & & \\
Total & 15 & 4756916 & & & & \\
\hline
\end{tabular}

Remarks: ${ }^{\mathrm{n}}=$ significant $;{ }^{\mathrm{t}}=$ not significant; SC $=$ Source of convergence; DF: Degrees of Freedom; SS = Sum of squares; MS = Mean squares

in treatment A. Goats receiving a high-level of grass compared to goats receiving a highlevel of grass mixed with legumes showed no significant difference with regard to the fodder consumed (Ngitung, Hasan, Sonjaya \& Pakiding, 2013). This may have been because of the legume being fed was refused by the goats. Consumption will be greater for preferred fodder if it is fed continuously to ruminants as there is an increase in microbial activity and the rates of fermentation and digestibility, and the amount of consumption will increase (Aryanto, Suwignyo, \& Panjono, 2013).

Treatments involving the addition of different amounts of green mantangan indicated that the amount of consumed food was smaller. This may have been caused by that mantangan was consumed before the grass being sufficient to satisfy the needs of the goats and so the subsequent amount of grass consumed was not as high. Mantangan has a high protein content $(9.7 \%)$ compared to field grasses, which was only $2.78 \%$ (Garsetiasih, 2007). The total amount of grass consumed was high for the controlled treatments possibly because field grasses are the fodder the goats prefer and these are what are ordinarily eaten when there is no other choice of fodder. When small ruminants graze and browse under extensive conditions, goats have a habit of selecting their feed carefully when eating and are considered to be browsers, and utilise a wide range of native range plants, including foliage from trees and shrubs, forbs and grasses throughout the year (Sanon et al., 2007; Ngwa et al., 2000). Goats given the green mantangan may need more time to adapt, so that they eat it by preference. Goats fed on added mantangan fodder consumed less food compared to ones that only received green grass (Table 2). Based 
on the statistical analyses (Table 3), the periods of feeding treatments and the levels of feeding (A, B, C, D) were significantly different in every period of goat treatment.

The levels of treatments affected the amount of food consumed. For example, the amount of food consumed in treatment B (grass +200 g mantangan) was significantly different to treatment $A$ (the control) and treatment D, (grass $+600 \mathrm{~g}$ mantangan). Treatment $\mathrm{C}$ (grass $+400 \mathrm{~g}$ mantangan) was significantly different to treatment $A$, but was not significantly different to treatment D. This was possible because the mantangan was sufficient in both quantity and quality for the goats and so it replaced their need for grass and they consequently consumed less grass. Besides it's high protein content, mantangan also has a high amount of raw fiber $(39.85 \%)$ which was satisfied the goats need for roughage. The higher the raw fiber content in fodder, the less digestion occurs of the food consumed, so consumption decreases (Mulyaningsih, 2006). Mantangan was able to be used as green fodder for the livestock. Goats in the young growth state weighing less than $10 \mathrm{~kg}$ in addition to being fed grass, can be fed to $600 \mathrm{~g}$ of green matangan. The rate of mantangan provided can be increased appropriately as the growth state and body weight of the goat increases.

\section{B. Incremental Body Weight of Goats}

The average weight increment of the goats in each period fluctuated with the treatment, being $0.325 \mathrm{~kg}$ when fed grass $+200 \mathrm{~g}$ mantangan (treatment B) and $0.675 \mathrm{~kg}$ for the only grass control (treatment A), as shown in Table 3. Based on the statistical analyses, the level of mantangan feeding did not significantly affect body weight increment, but qualitatively there were differences in body weight increment among treatments, with treatment $\mathrm{B}$ having a smaller body weight increment, followed by treatments $\mathrm{C}$ and $\mathrm{D}$, respectively.

Treatment A (only grass without mantangan) produced a higher body weight increment (675 $\mathrm{g}$ per periods) with this treatment also having the highest consumption of fodder. This was consistent with the results reported by Kartadisastra (1997) who found that the body weight of livestock increased directly with the level of fodder consumption. Ismoyo and Widiyaningrum (2008) stated that there was a relationship between the sum of food consumed and its digestibility, with the greater the amount of food consumed, the greater the body weight increase. The body weight increment was not much different for treatment D (grass +600 g mantangan), namely, 575 g. Thus, to utilize the mantangan that had invaded the area, it is suggested that mantangan be fed at $600 \mathrm{~g}$ per individual goat per day while the goat is still in the growth stage.

\section{Nutritional Content of M. peltata}

Mantangan ( $M$. peltata) is green foliage species that has potential to be used as fodder in the National Park, where mantangan is eaten by deer and other wild herbivores as a source of green food. The proximate analysis measured

Table 3. Body weight increment of goat in each treatment $(\mathrm{kg} /$ individual/day)

\begin{tabular}{cllll}
\hline \multirow{2}{*}{ Period } & \multicolumn{5}{c}{ Treatment } \\
\cline { 2 - 5 } & $\mathrm{A}$ & $\mathrm{B}$ & $\mathrm{C}$ & $\mathrm{D}$ \\
\hline I & 0.2 & -0.5 & 0.2 & 0.8 \\
II & 1.5 & 0.3 & 0.7 & 0.8 \\
III & 0.5 & 0.5 & 0.5 & 0.5 \\
IV & 0.5 & 1 & 0.5 & 0.2 \\
\hline Total & 2.7 & 1.3 & 1.9 & 2.3 \\
\hline Average & 0.675 & 0.325 & 0.475 & 0.575 \\
\hline
\end{tabular}

Remarks: A: field grass without mantangan, B: field grass (ad libitum) $+200 \mathrm{~g}$ mantangan, C: field grass (ad libitum) + $400 \mathrm{~g}$ mantangan, D: field grass (ad libitum) + $600 \mathrm{~g}$ mantangan 
Table 4. Nutrient content of mantangan ( $M$. peltata)

\begin{tabular}{|c|c|c|c|c|c|c|c|c|c|}
\hline \multirow{2}{*}{ Location } & \multicolumn{9}{|c|}{ Mantangan nutrient content $(\%)$} \\
\hline & $\mathrm{DM}$ & Ash & $\mathrm{CP}$ & $\mathrm{CF}$ & $\mathrm{CE}$ & $\mathrm{Nfe}$ & $\mathrm{Ca}$ & $\mathrm{P}$ & $\mathrm{GE}(\mathrm{kal} / \mathrm{g})$ \\
\hline Tamling BBSNP & 89.30 & 6.56 & 9.70 & 39.85 & 3.29 & 29.90 & 1.26 & 0.30 & 4087 \\
\hline
\end{tabular}

Remarks: DM = Dry matter; $\mathrm{CP}=$ Crude protein; $\mathrm{CF}=$ Crude fiber; $\mathrm{CE}=$ Crude ether; NFE = Nitrogen-free extract; $\mathrm{Ca}=$ Calcium; $\mathrm{P}=$ Phosphorus; $\mathrm{GE}=$ Gross energy $(\mathrm{cal} / \mathrm{g})$

the levels of some nutrients to determine their suitability for livestock or wild herbivores as the main food source. The results are presented in Table 4.

The contents of fat, calcium, and phosphorus of mantangan exceeded those of lamuran grass, further adding to the potential of using mantangan as fodder for livestock. Wild herbivores or livestock need nutritional elements for their growth and mantangan has not only quality potential but also quantity since it is abundant and widespread in the buffer zone of BBSNP and within the National Park.

Treatments consisting of green field grass with the addition of some mantangan foliage statistically did not have any effect on body weight, but treatment A (only grass) and treatment D (grass $+600 \mathrm{~g}$ mantangan) resulted in higher increments in body weight than the other treatments (adding $200 \mathrm{~g}$ or 400 g mantangan). Mantangan showed potential as a green fodder source for livestock, especially goats, because of its high nutritional content compared to field grasses, and in particular, with regard to protein, fat, calcium and phosphorus. Feeding IAS to large-bodied herbivores, such as cows, sheep, and goats, could be effective in suppressing dominant (IAS) plants and support local economics by generating valuable goods, such as meat, milk, and leather (Esselink et al., 2002). In the past century, the appearance of IAS and their impact on ecosystem has become apparent. The spreading of species beyond their natural habitat has been contributed by the development of transportation and international trade (Hussner et al., 2010; Lenda et al., 2014).

\section{CONCLUSION}

Mantangan is relatively high with a protein content of $9.70 \%$ and an energy content of 4087 calories. The protein content was higher than in field grass Paspalum conjugatum (8.85\%), Panicum repens $(7.54 \%)$ that are usually grazed by goats in Lampung Province. The protein and energy contents have a substantial effect on body weight increment. The acceleration in weight growth depends on the quality of the food being consumed, with higher protein content in the fodder the consumption of dry matter increasing that is used for growth.

The results of this study have implications for the management of the area including, Merremia peltata as an alternative animal feed, and rehabilitation to restore the authenticity of species and increase ecological functions. In addition, management that includes ecological, economic and social aspects needs to be improved through the selection of appropriate native species for plant enrichment, and control during the succession process.

\section{ACKNOWLEDGEMENT}

The writer is grateful to the head officer of the BBSNP, the head of Kampung Tampang Tua village in Tanggamus District, the Forest Rangers of Tampang Muda Resorts, the two technicians, Carlan and Najmullah, and local community leaders who contributed to research activities. For his much-valued assistance, we would like to thank Dr. Andrew John Warner. 


\section{REFERENCES}

Aryanto B., Suwignyo, \& Panjono. (2013). Reduction effects and the fulfillment of the amount of feed back on consumption and digestibility of feed ingredients on goats (Capra bircus) and peranakan etawah. Livestock Bulletin, $37(1), 12-18$.

Alikodra, H.S. (2010.) Wildlife management techniques in order to maintain biodiversity Indonesia. Bogor: IPB Press.

Esselink P., Zijlstra W., Dijkema K.S., \& Van Diggelen R. (2002). The effects of decreased management on plant-species distribution patterns in a salt marsh nature reserve in the Wadden Sea. Biological Conservation, 93,61-76.

Bappenas [National Development Planning Agency]. (2003). Strategy and action plan for biodiversity Indonesia 2003- 2010. Report. Jakarta.

Garsetiasih, R. (2014). Eradication technique of invasive species flora in Bukit Barisan Selatan National Park and Baluran National Park. Research Report. Bogor. Research and Development Center for Conservation and Rehabilitation, FORDA, The Ministry of Forestry, Bogor.

Garsetiasih, R. (2007). The digestibility of corn and grasses as a feed of deer (Cervus timorensis). Germplasm Bulletin, 13(2), 88-92.

Gomez, K. A. \& Gomez, A.A. (2010). Statistical procedures for agricultural research. In E. Syamsudin, J. S. Baharsyah (Translator). $\left(2^{\text {nd }}\right.$ Edition). Jakarta: UI Press.

Hakim, L. \& Miyakawa, H. (2015). Exotic plant species in the restoration project Area in ranupani recreation forest, Bromo Tengger Semeru National Park (Indonesia). Biodiversity Journal, 6(4), 831-836.

Hussner A., van de Weyer K, Gross E.M., \& Hilt S.(2010). Comments on increasing number and abundance of nonindigenous aquatic macrophyte species in Germany. Weed Research 50, 519-526.

Irianto, R. \& Tjitrosoedirdjo, S. (2010). Invasion of Merremia peltata (L.) Merr., convolvulaceae in Bukit Barisan Selatan National Park, Indonesia. Journal of Tropical Weeds and Invasive Plants, I(2), 65-70.
Ismoyo \& Widiyaningrum. (2008). The influence of the interval feeding concentrates and forages on the productivity of the peranakan etawah goat weaning. Scientific Journal of Animal Husbandry Sciences XI, (2), 70-74.

Jaelani, A., Rostini, T., Zakir, M.I. \& Jonathan. (2014). Effect of forage bog bean fermentation to the appearance of goats (Capra bircus). Journal of Animal Husbandry Science, 12 (2), 76-85.

Kartadisastra. (1997). The provision and management of ruminant feed. Yogyakarta: Kanisius.

Kolada A. \& Sebastian, K. (2016). Elodea canadensis (Michx.) in polish lakes: A non-aggressive addition to native flora. Biology Invasions, 18, 3251-3264.

Lenda M., Sko'rka P, Knops J. M. H, Moron' D., Sutherland W. J, Kruszewska K., Woyciechowski M. (2014) Effect of the internet commerce in dispersal modes of invasive alien species. PLoS one, 9(6), 86-99.

Mardiati Y, Triadiati T, Soekisman T. (2018). Physiological character of Merremia peltata (L.) Merrill from Bukit Barisan Selatan National Park Lampung. Hayati Journal Bioscince, 25 (1), 25-30.

Master J., Tjitrosoedirdjo S. S, Qayim I., Tjitrosoedirdjo S. (2013). Ecological impact of Merremia peltata Nerrill invasion on plant diversity at Bukit Barisan Selatan National Park. Biotropia, 20, 29-37.

Mattjik, A.A.\& Sumertajaya,I.M. (2002). Experiment design. Bogor: IPB Press.

Mulyaningsih, T. (2006). Appearance thin tail sheep (Ovies aries) males were fattened with some counter weight to concentrate and grasses (Pennisetum purpureum). Thesis. Animal Production Technology Studies Program Faculty of Animal Husbandry, Bogor Agricultural University, Bogor, Indonesia.

Ngwa, A.T., Pone, D.K., \& Mafeni, J.M. (2000). Feed selection and dietary preferences of forage by small ruminants grazing natural pastures in the Sahelian zone of Cameroon. Animal Feed Science and Technology, 88 (3), 253-266.

Ngitung, R., Hasan S., Sonjaya H., \& Pakiding W. (2013). Response of marica goats reared intensively ex-situ on the provision of different forages. Bionature Journal, 14(2), 117-121. 
Paynter. Q., Harman H., \& Waipara N. (2006). Prospects for biological control of Merremia peltata. Landcare Research Private Bag 92170. Auckland, New Zealand.

Pyšek P., Bacher S., Chytrý M., Jarošík V., Wild J., Celesti-Grapow L., Gassó N.,....., \& Hulme P. E. (2010): Contrasting patterns in the invasions of European terrestrial and freshwater habitats by alien plants, insects and vertebrates. Global Ecology Biogeogrphy. 19, 317-331.

Rudiah. (2011). Response of male goats (Capra bircus) to the feeding time. Research Media Southeast Sulawesi, IV 1, 67-74.

Sally, J., Creighton, L., \& Lehman, A. (2005). JMP start statistic second. A guide to statistics and data analysis using JMP and JMP IN software. North Carolina.

Sanon, H.O., Kaboré-Zoungrana, C., \& Ledin, I. (2007). Behaviour of goats, sheep and cattle and their selection of browse species on natural pasture in a Sahelian area. Small Ruminant Research, 67(1), 64-74.

Suparno. (1994). Science and technology of meat. Yogyakarta: Gadjah Mada University Press.

Suyadi. (2011). Deforestation in Bukit Barisan Selatan National Park, Sumatrae, Indonesia. Journal Biology Indonesia, 7, 195-206.
Tahuk, P.K., Baliarti, E., Hartadi, H. (2008). Performance of bligon goats on fattening with different of feed protein levels. Livestock Bulletin, 32(2), 121-135.

Thomaz S. M., Kovalenko K.E., Havel J.E., \& Kats L. B. (2015). Aquatic invasive species: General trends in the literature and introduction to the special issue. Hydrobiologia, 746, 1-12.

Tjitrosoedirdjo, S. (2010). The concept of weeds and invasive plants. Journal of Tropical Weeds and Invasive Plants. 1(2), 89-100.

Tillman. A.D., Day, H., Soedomo, R., Suharto, P. I., \& Soekanto, L. (1984). Science of fodder base. Yogyakarta: Gadjah Mada University Press.

van Kleunen, M., Weber E., \& Fischer M. (2010). A meta-analysis of trait differences between invasive and non-invasive plant species. Ecology Letters, 13, 235-245.

Yansen, Wiryono, Deselina, F. Hidayat, \& K. Depari. (2015). The expansion of Merremia peltata (L.) Merrill in fragmented forest of Bukit Barisan Selatan National park enhanced by its ecophysiological attribute. Biotropia, 22(1), 25-32. 